\title{
MUSLIM PIETY AND FOOD OF THE GODS
}

\author{
David WAINES \\ Lancaster University
}

\section{INTRODUCTION: THE THEOLOGY OF FEAR}

In the discipline of Religious Studies, it is a cause of some bemusement to both practitioners and detractors alike that «religion» cannot be universally and precisely defined. Sixteenth century, essentially Catholic understandings of «religion», related to ritual practice while two centuries later, ritual was being de-emphasised and the term, from a Protestant perspective, seemed to reflect more a believer's state of mind. By the turn of the twentieth century, James Leuba famously listed more than fifty definitions of religion in the appendix to his Psychological Study of Religion (1912). At the end of the same century J. Z. Smith concluded his survey of the word, observing that it was not a native term but rather «one created by scholars for their intellectual purposes and therefore is theirs to define.» ${ }^{1}$ This situation had earlier prompted W. C. Smith to suggest abandoning the term «religion» altogether. ${ }^{2} \mathrm{He}$ was more concerned to explore and reveal the vitality of the multiple, cumulative historical traditions and the living faith of the individuals within them. Islam, for example, appears to be unique among the world's «faith traditions» in having named itself, rather than being named by others. Islam then is a native term, unlike Mahometan or Saracen, as in the traditional European perspective. But is it a «religion»? The term Isläm, as it appears in the Qur'an, is not the name for a religious system but is «the designation of a decisive personal act.» ${ }^{3}$ The Qur'anic term din, says Smith, may seem a close equivalent to the European word, 'religion' ${ }^{4}$ This latter term, however, historically associated with classical and medieval 'European' traditions, when applied to those beyond Europe, inevitably carries

\footnotetext{
${ }^{1}$ Smith, Johnathan Z., «Religion, religions, religious», in Taylor, Mark C. (ed.), Critical terms for Religious studies, Chicago, University of Chicago Press, 1998, p. 281. Smith also draws attention (p. 272) to David Pailin's unpublished paper (1994) that the notion of «natural religion» is employed in the literature in at least eleven «significantly different» ways.

2 See his The Meaning and End of Religion, Toronto, 1962, p. 138 where his position is succinctly expressed in these words, that «fundamentally one has to do not with religions, but with religious persons.»

${ }^{3}$ Ibid., p. 101. And also p. 103. «Vivid and dynamic — and personal: these are the qualities of the term Isläm in the Qur'an. What was proclaimed was a challenge, not a religion.»

${ }^{4}$ Ibid., p. 76
} 
with it the shifting meanings and imprecision used within the several Christian traditions as well as in the more recent, secular studies of religion. Hence the locution «faith tradition» could be employed as an adequate rendering of the Islamic term din.

These preliminary remarks serve to introduce the main theme of this paper, an exploration of another term from the Islamic tradition that also poses a problem of meaning when translated into European languages. The Arabic term is taqwa , from the verbal root $w-q-y$ (VIII form ittaq $\bar{a}$ ). It is sometimes rendered as «piety», but not always; this in itself constitutes part of the problem, as we shall see. For example, the term 'piety' in the languages of two Christian cultures, English and Spanish, may be described as follows. The Oxford Universal Dictionary defines «piety» as the «habitual reverence and obedience to God (or the gods)» and in a secondary sense as «faithfulness to the duties naturally owed to parents and relatives, superiors, etc.» The dictionary of the Spanish Real Academia defines 'piedad' as: «virtud que inspira por el amor de Dios tierna devoción a las cosas santas; y por el amor al prójimo, actos de abnegación y compasión.» The Spanish version seems more inclusive, since piety is directed to «cosas santas», a somewhat broader compass than simply God or the gods. A more important aspect is that, in the Academy's version, piety is motivated by 'love', an expression familiar to a Christian reader, Catholic or Protestant. Piety is a sign of the Christian's love of God, that deity being the Christian's God of Love. Does love of God constitute part of the Muslim's concept of piety; or does taqwā as 'piety' contain an element of love? The point here is simply that the search for equivalents between languages can at the best of times lead to imprecise results; even more so when the terms in two languages carry with them such weighty and very different historical-cultural baggage.

A good illustration of this problem is the application of a Christian theological understanding of the term 'piety' to the message of the Qur'an. The Protestant theologian and scholar of Islam, Tor Andrae, sets out to describe the «heart of Muhammedan piety» as historically related to «the basic mood of Christian ascetic piety as it survived in the Oriental churches, and where likewise it had become the ideal and norm of the laity in a much higher degree than was the case in the West.» ${ }^{5}$ This was based upon «The deep earnestness, the keen

\footnotetext{
${ }^{5}$ Mohammed: the Man and his Faith, New York, 1960 [1936], p. 83.
} 
expectation of future life, the contrition and trembling before the Day of Judgement, fear as an actual proof of piety, (and) the warning against the carelessness which forgets responsibility and retribution.» Fear as the proof of piety is fundamental, «characteristic of all really genuine piety; the believer must cultivate fear. It is the only road to salvation.» 6

Andrae's exposition directly influenced the classic study of the EthicReligious Concepts in the Qur'an by the late Japanese scholar Toshihiko Izutsu. In his detailed semantic analysis of Qur'anic ethical terms, Izutsu writes: «'Belief' is the real fountainhead of all Islamic virtues; it creates them all, and no virtue is thinkable in Islam, which is not based on a sincere faith in God and His revelations.» ${ }^{7}$ When Izutsu asks «what are the characteristic features of 'belief'?» or «how is a believer expected to behave socially as well as religiously?», an unambiguous term for piety alone does not appear either as part of the inner structure of 'belief' or as a feature of a Muslim's behaviour. Included, however, is the Arabic term taqwā, noted above, rendered as «fear of God.» Echoing Andrae, Izutsu also sees fear as the proof of piety as it arouses in a believer «a clear consciousness of the tremendous seriousness of life and thus incites him to moral earnestness and responsibility.» ${ }^{8}$ Another term, birr, rendered variously as 'righteousness', 'kindness', 'piety' etc. is, according to Izutsu, the vaguest and most elusive of all Qur'anic moral terms, as none of these translations alone do justice to the original which «includes all these and perhaps still others in its complex meaning.» ${ }^{9}$ In two important Qur'anic passages (Q 2:177, 189), the imprecise term birr is found in close association with taqwā which, for Izutsu, unambiguously means «fear of God» and «godfearing.» These passages best reflect Izutsu's adherence to Andrae's theological position.

Izutsu devotes a whole section ${ }^{10}$ to the 'fear of God' (taqwa) which, he says, does belong to the essential qualities of the true believer. Fear is, indeed, «the most fundamental motif of this new religion, that underlies all its aspects and

6 Ibid.

7 Montreal, 1966, p. 184.

8 Ibid., p. 54; cf. Andrae, Mohammed, p. 73. It is important to note that Andrae defines Muslim taqwä in terms of eastern Christian monastic asceticism; Izutsu acknowledges that taqwa (based upon fear) in the sense of acting as though one stood right now before the divine judge became a central theme of the early Muslim ascetics, exemplified in the life of Hasan al-Bașin. It would be worth a separate study to investigate whether Muslim ascetics and Sufis employed the term taqwa to mean a cultivated pious fear of God in a sense different from that understood by ordinary believers.

9 Ibid., p. 208.

${ }^{10}$ Ibid., pp. 195-200. 
determines its basic mood.» ${ }^{11}$ A fitting definition of the true believer is 'one who trembles in fear before God.' This emotion is derived from the atmosphere established in the early parts of the Qur'an, taqwā being related to an eschatological fear of the catastrophic Hour. ${ }^{12}$ The presence of a basic emotion of fear, he adds, is underlined by passages where verbal or nominal forms of khāshiya and khäfa, both meaning to fear, exist together with words derived from ittaq $\bar{a} .{ }^{13}$

Izutsu's analysis establishes what we may call a «theology of fear», based upon his fundamental equation of 'belief' and 'fear', supported by Andrae's theological interpretation. Apart from the vagueness of the word birr, there is little or no room in the Qur'an for a notion of simple 'piety', untainted with the emotion of fear.

The problem with Izutsu's argument is not an inherent weakness in the method of semantic analysis, but rather in an application which can produce a misleading picture. First, we have seen that the term birr could be translated by several terms in English, among them 'piety'. It is, in other words, polyvalent. On the other hand, taqwā for Izutsu is monovalent and means only 'fear' and nothing else. He does not, however, establish clearly how he arrived at that application. For example, there is a verse (Q 39:16), cited by Izutsu, in which two well known English translations of the Qur'an also render the verb ittaqa as 'fear':

- [Dawood] By this God puts fear (yukhawwif bihi) into His servants' hearts; Fear Me (ittaqūnī) then, My servants.

- [Pickthall] With this doth Allah appall (yukhawwif bihi) his bondman.

O my bondman, therefore fear Me (ittaqūnī)!

11 Ibid., p. 195. Fazlur Rahman (Major Themes in the Qur'an, Chicago, 1980) agrees that taqwā is «perhaps the most important single term in the Qur'an» which denotes «the fully integrated and whole personality» of individuals (p. 28). He notes, moreover, that the term has been translated to mean both «fear of God» and «piety» although the root of the word $w-q-y$ means "to guard or protect against something', found in this sense in various Qur'anic passages (52:27; 40:9; $40: 45 ; 76: 11)$. Rahman then adds «Hence taqwā means to protect oneself against the harmful or evil consequences of one's conduct. If, then, by 'fear of God' one means fear of the consequences of one's actions - whether in this world or the next (fear of punishment of the Last Day) - one is absolutely right.» (p. 29).

${ }^{12}$ Izutsu, Concepts, pp. 53-54.

13 See Q 24:52 and 39:16. 
The verb khawwafa (II form of khafā) 'to fill with fear', in its simple root form is an unambiguous term denoting this emotion. Its presence in close association with ittaqa allows this latter imperative to be correctly rendered, in this instance, as 'Fear!', a secondary sense of the VIII form of the verbal root $w-q-y$. But is this universally the case? In Q 6:51, for example, we find the verb yakhäfüna present again with yattaqūna. After the phrase «Warn those who dread (yakhäfüna)», Dawood renders the following yattaqūna as 'so they may guard themselves against sin', while Pickthall makes it read «that they may ward off (evil).» The two passages, Q 39:16 and Q 6:51 are nevertheless distinct, the subtle difference reflected correctly in the Dawood-Pickthall translations of both passages. It would take us too far beyond the purpose of this paper to explore all the instances of the verbal form ittaq $\bar{a}$, even in these two translations. Suffice it to say that in the example just noted (Q 6:51), ittaqā has not been reduced, as in Izutsu's scheme, simply to fear. The senses of 'guarding oneself against sin' and 'warding off (evil)' are close enough to each other to express the verbal meaning of ittaqa and are helpful circumlocutions expressing a basic notion of 'piety', except in cases (as above) where the context more clearly favours the more nuanced notion of fear. As for the noun taqwā, Dawood and Pickthall employ a variety of terms: 'piety', 'what is right', 'righteousness', 'devotion', 'devout', 'duty (to Allāh), and 'more proper'. It should be evident by now that, in contrast to Izutsu's theologically assisted interpretation, taqwā and its derivatives are as polyvalent as the term birr. That does not, however, mean they are useless in an exploration of the rich content of taqwā in Muslim scripture.

Finally, we may note one key passage that Izutsu uses to illustrate his method of reaching 'contextual definitions' of major ethical terms. In the following passage «the precise meaning of a word is elucidated concretely in its context by verbal description.» ${ }^{14}$ The word in question is birr, and in Izutsu's translation reads as follows:

Birr (righteousness, piety, kindness) does not consist in whether you face the East or the West, but [true] birr is this, that one believes in God, and the Last Day, and the angels, and the Scripture, and the prophets; that one gives one's own wealth, howsoever cherished it may be, to kinsfolk, orphans, the needy, the wayfarer, and beggars, and for the sake of [the liberation] of slaves: that one

${ }^{14}$ Izutsu, Concepts, p. 37. 
performs the ritual prayer, pays the alms. And those who keep their covenant when they have once covenanted and are patient in distress and hardship: these are they who are sincere (sadaqu$)$; these are they who are godfearing (muttaqin) (Q 2:177).

Izutsu notes that birr is «a kind of social righteousness» ${ }^{15}$ which «manifests itself in various actions motivated by the will to practice justice and love towards others.» ${ }^{16}$ It does not follow, however, that «moral earnestness» and «responsibility» emanate solely from or necessarily entail a fear of God. Rather, they are constructed from a conscious and gradual internalization of a pious attitude towards God which embraces, as in this passage, beliefs, the willing support of family and the needy, the performance of prescribed rituals, being true to one's word, and adopting an attitude of forbearance in the face of difficulties. These are the qualities of sincere believers (alladhina șadaqū) and, if we adopt a different rendering from Izutsu's for muttaqin along the lines argued above, we can conclude that the passage equally provides a contextual definition for «the pious» or for «those who ward off evil.» ${ }^{17}$

In this second part of this essay, we shall explore more fully the notion of taqwā from material provided by two of the best known commentators on the Qu'ran, al-Tabarī and Ibn Kathïr. In dealing with such central Qur' anic concepts as taqwa , this offers a way forward in presenting a more nuanced picture of how Muslims read their sacred text. The particular focus will deal with the response to the divine command expressed in rituals, included as part of 'being pious' in the passage (Q 2:177) cited above, but more especially to certain prohibitions connected with food taboos mentioned in the Qur'an.

\section{PIETY, RITUAL AND THE FOOD OF THE GODS}

Ibn Kathìr (d. 774/1372) offers a useful exegesis upon the passage we have just been considering, Q 2:177, on the nature of birr and taqwā. He commences

15 Ibid.

16 Ibid., p. 207.

17 It is interesting that in this passage, Pickthall who generally avoids a 'theology of fear', translates muttaqin as 'God-fearing'. Muhammad Asad, alone of the translators consulted, renders the term as 'those who are conscious of God'. Other English versions by Palmer, E. H. (1880), Rodwell, J. M. (1909), Yusuf Ali (1946), Arberry, A. J. (1955) and the Spanish versions by Cortés, J. and Vernet, J., all adopt a 'theology of fear'. 
by observing that «this noble verse comprises a number of important matters embracing general foundations (qawā'id 'amima) and a sound doctrine ('aqìda mustaqima) of faith»; this is illustrated by the occasion when the Prophet's companion Abū Dharr asked him what was the meaning of faith (imān) and the Prophet answered by reciting this verse in full. Ibn Kathīr cites a (munqati ${ }^{\circ}$ ) tradition from the Prophet transmitted by the same companion to the effect that "When you do a good deed your heart loves it, and when you perform a bad deed, your heart abhors it.» Birr, taqwā and complete faith (imān kāmil) entail obedience to Allāh, compliance with His commands and following what He has prescribed. This means that obedience does not entail doing something that Allāh has not commanded or prescribed. That is, according to the verse, righteousness does not consist in turning east or west in prayer, or anywhere else, but only in the direction commanded by Allāh. Those who could be described by the qualities enumerated in the verse are sincere in their faith (ulà'ika alladhina sadaqū) because they implement the inner faith of the heart (al-imän al-qalbi) by their words and deeds in practice. They are muttaqün, 'pious' because they guard themselves against the commission of the taboos and prohibitions and perform acts of obedience in accord with Allāh's commands (li-annahum ittaqū al-mahạarim wa fa'alū al-tāa'ât). The explanation by al-Tabarī (d. 319/923) of muttaqūn in this passage allows that fear is only one, and not necessarily the dominating, aspect of several shaping a believer's makeup, such as guarding against God's punishment, avoiding disobedience, preparing for God's promise, not overstepping His decreed limits and discharging His commands.

It will be recalled that Q 2:177 mentions the rituals of prayer and the giving of alms, behavior essential to the righteous and pious. Other ritual obligations, fasting and pilgrimage, are cited in slightly later verses. For example, in Q 2:183 it reads, in Dawood's translation, «Believers, fasting is decreed for you as it was decreed for those before you; perchance you will guard yourself against evil (tattaqūna).»In al-Ṭabarī's commentary, this refers to the fast of Ramadān; the evils to be guarded against are food, drink and sexual intercourse during the prohibited period of the day. Then in Q 2:197, we read, again in Dawood's translation, «Make the pilgrimage in the appointed months... Provide well for yourselves; the best provision is piety $(\operatorname{taqw} \bar{a})$. Fear me (wa'ttaqū $\bar{\imath})$, then, you that are endowed with understanding!» ${ }^{18}$. Al-T Tabarī explains taqwā here to

18 Pickthall's translation reads 'the best provision is to ward off evil. Therefore keep your duty to Me...'. 
mean «doing something in obedience of God.» As for the cautionary imperative to those who understand, al-Tabarī suggests the sense of God's saying to his creatures, «Fear my punishment by avoiding those of my prohibitions which I have imposed upon you», all being part of God's law or way (din). Al-Tabarī deals more fully with the term muttaqin on its first occurrence in Q 2:2, which was closely followed by Ibn Kathīr in his commentary. Neither statement admits an element of fear in the definition of taqwa. . Al-Tabarı̄’s formula reads: «Those who do their duty to God guard against committing what He had forbidden them, hence avoiding disobedience, and who do their duty to Him in the obligations He has commanded, hence obeying Him in executing them.» The rituals of prayer, alms giving, fasting and pilgrimage are among the obligatory elements of Islamic worship, the omission of which is punishable in the afterlife while, in addition, other actions are forbidden absolutely, their commission being punishable in the hereafter. It is to these latter actions in relation to food prohibitions that we now turn.

In Q 5:4, which belongs to the first and most detailed passage on food taboos, the status of game caught by trained hunting birds and animals is mentioned. Dawood's translation reads as follows: «Eat of that which they have caught for you, pronouncing upon it the name of God (wa-dhkuru ism allāh 'alayhī). And have fear (ittaqū) of God: swift is God's reckoning.» Pickthall's rendering of the second sentence is predictably different: «and observe your duty to Allāh: Lo! Allāh is swift to take account.» Al-Ṭabarī interprets this passage to mean: «O people, ittaqū allāh in matters which $\mathrm{He}$ has commanded you and be on guard in that respect (ihdharūhu) against adopting a role deviating from (God's command).» The close equivalence between the verbs ittaqa and hadhira, the latter meaning variously 'to be cautious, wary, vigilant' (Lane) is clearly preferable to its secondary sense of 'to be in fear'.

The injunction to consecrate a slaughtered animal in the name of Allāh occurs as well in the previous verse listing the food taboos a Muslim must adhere to: «You are forbidden (hurrimat 'alaykum) carrion, blood and the flesh of swine; also any flesh dedicated to other than God (wa mà uhilla li-ghayr alläh).» ${ }^{19}$ The verse continues: «You are forbidden the flesh of strangled animals and of those beaten and gored to death; of those killed by a fall or mangled by

19 See also Q: $2: 173 ; 6: 145 ; 16: 115$ for similar passages, and $6: 118,119,121$ for its use with the verb dhakara. 
beasts of prey (unless you make it clean by giving the death stroke yourselves); also of animals sacrificed to idols.» These are explicit and absolute prohibitions, signaled by the phrase hurrimat 'alaykum.

Once again Ibn Kathīr offers an interesting insight into the behavior appropriate to what is permitted and forbidden in food and drink. In a passage Q 7:31 where the children of Adam are urged to dress well when attending a place of worship, it says: «Eat and drink, but avoid excess. (Allāh) does not love the intemperate.» Ibn Kathīr cites a tradition preserved by Ahmad b. Hanbal in which the Prophet observed that Allāh wished to see His favour borne by his servants without arrogance or extravagance so they should eat, drink, dress and give alms accordingly. From another source Ibn Kathïr provides the explanation that:

In matters of the permitted (halāl) and the forbidden (harām) the limit in each case is not to exceed the proper bounds; that is, within the category of the permitted one should not then seek to legitimize or rationalize what is forbidden, nor to include within the category of the forbidden what is in fact permitted. Allāh wishes only to allow what he declared legal and forbid what he declared prohibited and that in this matter there is a (just and fine) balance ( $a l$ - ' $a d l$ ).

We shall now see how this notion of balance or discernment may be applied further in exceptional conditions regarding food prohibitions.

\section{CONDITIONS CIRCUMSCRIBING FOOD TABOOS}

1. The first condition is covered by the above phrase 'unless you make it clean' (illa mā dhakkitum). That is, the preceding categories of carcass —strangled animals, etc.- - are allowed, according to al-Tabarî's explanation, if the animal were still alive, evidenced by its blinking an eye, wagging its tail or making some other movement, and then it could be sacrificed by consecrating it to Allāh in the legal manner. For Medinans, however, these animals were forbidden regardless.

Al-Tabari adds the important observation that sacrificing an animal in the name of Allāh marked a crucial demarcation between believers and mushrikūn who sacrificed these animals in the name of their own gods. The theme is reiterated in the various contexts treating of the food taboos. The cause for this injunction being given to Muhammad was the occasion when some idolaters 
visited the Prophet and asked him, «When a sheep dies, who or what caused it to die?». The Prophet replied that it was Allāh. To which the idolaters' chiding retort was, "You claim that what you and your companions slaughter is permissible to eat, but what God kills is forbidden!» They understood that what Allāh caused to die fell into the category of carrion (mayta) and was therefore forbidden to Muslims. Thereafter Allăh revealed the verse 'Do not eat that which has not been consecrated in the name of God.'

Food and rituals associated with it are well known community emblems and as markers separating one group from another. ${ }^{20}$ The Qur'an illustrates this in other passages where the distinction between unbelievers and believers is spelled out. Worshippers of idols (andād) when asked to follow what Allāh has revealed, replied: «We will follow what our fathers practiced.» Tribal custom in other words would prevail over the command of Allāh. Among these pagan customs, four kinds of sacrificial animal were rejected by Allāh (Q 5:103): bahìra, să'ibah, wașila and hâmì. According to Lane, a bahịra was a she camel (or ewe of female goat) who had brought forth five young, the fifth of which was a male. The male could be slaughtered and eaten by men. But if the fifth were female, then its ear was slit and it was free to pasture. Its flesh and milk were forbidden and it could not be used for riding. When this privileged beast died, its flesh was then lawful to women to eat. ${ }^{21}$ From a Qur'anic perspective, these food taboos belonged to a past in which custom and the moral economy were cultural constructs of man and did not emanate from divine guidance. The contrast is expressed in the verse in which idolaters say: «These animals and these crops are forbidden. None may eat of them save those whom we permit.» (Q 6:138). Allāh, on the other hand, enjoins believers to «eat of what is lawful and wholesome on the earth and do not walk in Satan's footsteps, for he is your inveterate foe» $(\mathrm{Q} 2: 168) .{ }^{22}$ What was lawful to believers, as we have seen, was first, flesh over which His name had been pronounced with the exception of the specific categories cited in Q 5:3, and second, the harvest of the field crops and orchards. Al-Tabarī, commenting on Q 6:142, notes that the idolaters' prohibitions are tantamount to denying the sustenance provided by Allāh, and hence their perverse attitude is a defiance of the Compassionate One (al-raḥmān) and obedience of the devil. Al-Tabarī finds a somewhat different

\footnotetext{
${ }^{20}$ On this theme see Mary Douglas' essay on «The Abominations of Leviticus» in her work Purity and Danger, London, 1966.

21 Lane, Arabic-English Lexicon, s.v. b-h-r; see also Q 6:139.

22 See also Q 5:87-88 where a negative command is expressed first: «O believers! Forbid not the good things which Allāh has made lawful to you... Eat of that which Allāh has bestowed upon you as food lawful and good and keep your duty to Allāh [ittaqü].»
} 
explanation for idolaters' behavior in a passage where he argues that they claim some of their food taboos were in fact ordained by God. He dismisses these pretensions as again resulting from their walking in the devil's footsteps (Q 6:143-144).

Again, believers are urged to «eat of the wholesome things with which We have provided you and give thanks to God, if it is Him you worship» (Q 2:172). The expression of gratitude to the Creator for his beneficent provision is the only appropriate response for a believer, an attitude that must, therefore, be included among the general qualities of a pious person. This can be confirmed from a passage where the camel, part of the divine economy, is mentioned as a sacrificial animal whose flesh can be used to feed the poor and destitute. The passage concludes: «Their flesh and blood does not reach Allāh; it is your piety $($ taqwa $)$ that reaches Him. Thus He has subjected (camels) to your service, so that you may give glory to God for guiding you» ${ }^{23}$ (Q 22:35-37). A social duty demanded of believers was to be prepared to spend on others from what Allāh had bestowed upon them. This elicited from unbelievers (käfirūn) the reply: «Are we supposed to feed someone whom God can feed if he chooses? This is indeed a glaring error» $(\mathrm{Q}$ 36:47).

2. The second circumstance that makes the strict, albeit limited, taboos conditional occurs when the believer eats what is forbidden under duress. «He that is constrained by hunger to eat of what is forbidden, not intending to commit sin, will find Allāh forgiving and merciful» (Q 5:4). In a similar passage, hunger is not explicitly mentioned, and it reads: "Whoever is compelled by necessity» (Q 2:173) will be forgiven. ${ }^{24}$ Combining al-Tabari’s comments from the relevant passages, it is evident that one's experiencing simple hunger does not absolve him from the prohibition. Eating forbidden food is lawful only if one is struggling with the fear (khawf) that by not eating one's life would be in danger. Al-Tabari’s expression is interesting. The physical state of emaciation and psychological fear of death from hunger overpower the believer's pious intent to avoid the evil of consuming forbidden food. Less dramatic than this extreme condition, al-Tabari cites one source that defines the feeling of compulsion as a strong sense of revulsion, or repugnance at breaking the taboo. Nevertheless the conscious

\footnotetext{
23 The term for camel here is budn, pl. of badana, camels sacrificed at Mecca; see also Q. 80:24 where the phrase «Let man reflect on the food he eats» is a prelude to a description of the divine gift of rain and all it causes to spring forth on the earth; also Q 34:15: «Eat and give thanks.»

24 See also Q 6:119, 145.
} 
intention «neither to sin nor to transgress» is uppermost in the believer's heart and mind. This may be illustrated if a believer were captured by an enemy but induced in captivity to disobey Allăh by succumbing to His prohibitions; or, breaking the taboo is permitted and forgiven so long as one did not by that action intend to «sever the way (of Alläh), or to withdraw from the community or go forth in disobedience of Allāh.» The intent here, to guard against transgression of Allāh's command, is the mark of a believer's piety. Another passage ( $Q$ 6:119-121) which mentions the condition of compulsion, adds the explanatory phrase «Forsake the outwardness of sin and the inwardness thereof» (dharū zähir al-'ithmi wa bātinahu). Ibn Kathīr gives several interpretations, one from Mujāhid who says that $\sin \left(a l-{ }^{-} i t h m\right)$ in this sense is disobedience in the heart or thought (al-sirr) and in public, or the act of one who performs an act with deliberate intention. Ibn Kathïr draws attention to the similarity of Q 6:120 with Q 7:33: «My Lord only forbids indecencies, such of them as are apparent and such as are within.» He adds the hadith in which the Prophet responds to the question «what is $\sin ? »:$ :Sin (al-'ithm) is what is devised in your breast and which you would loathe that people might become aware of.»

An exceptional but instructive case which belongs strictly to neither of the above situations is found in Q 5:93: «No blame shall be attached to those that have embraced the faith and done good works in regard to any food they may have eaten, so long as they fulfil their pious duty to Allăh (ittaqū) and believe in Him and do good works; so long as they fulfil their pious duty to Allāh (ittaqū) and believe in Him; so long as they fulfil their pious duty to Allāh (ittaqu $\bar{u}$ ) and do good works. Allāh loves the charitable.» Al-Tabarī places this passage in its historical context of the Prophet's lifetime. He relates the verse to the earlier one (Q 5:90) in which the prohibition against wine was decreed as an 'abomination devised by Satan.' Prior to this decree, some of the Prophet's companions had indulged in wine drinking; of these, some died at the battle of Badr, others at Uhud. But owing to their faith and their good works, they were pardoned the wine they had drunk before its prohibition. Al-Tabari draws attention to the importance of the repeated phrase in the passage, that they were 'mindful of their pious duty to Alläh' a triple repetition of the verb ittaqu, and also its immediate association with the expressions, 'to believe' (the internal state) and 'to perform good works' (the external acts).

An eschatological context which also involves wine is Q 47:15. The reward in Paradise for those who 'kept their duty (to Allāh)' (ittaqū) are rivers of pure water, untainted milk, delicious wine, clear running honey and every kind of fruit'. This is, of course, a boundary marker between believers and unbelievers for the verse concludes: «Is this like the lot of those who shall abide in Hell forever, and drink scalding water which will tear their bowels?». 
In sum, the boundary between the community of believers and idol worshippers, unbelievers (käfirün) or other 'associationists' (mushrikün) when described in food terms, has both a ritual aspect and accompanying attitudes towards the preparation and consumption of foodstuffs. Avoidance of the specific categories of prohibited food and the ritual slaughter of an animal dedicated to Allāh are essential; prohibitions based on custom of human origin are not admitted, but only those divinely ordained. Gratitude to Allāh for food received and a willingness to share it with others are the positive social attitudes forming part of the profile of what it means to be pious; in a negative or personal sense, piety in connection with food prohibitions is displayed in the believer's being on guard against committing any infringement of the taboos. This is clearly evident in the emphasis placed upon a believer's internal state of mind or heart which only situations of extreme necessity would allow his crossing the boundary and committing an act forbidden by -a forgiving and compassionate- Allāh. That is, in Ibn Kathir's words, the believer fulfills in practice the heart's inner faith in both word and deed.

\section{CONCLUSION}

The concept of piety is clearly complex in any faith tradition. Difficulties immediately arise in trying to identify an adequate equivalent found in one language/ faith tradition, say English or Spanish Christianity, for that in another language/faith tradition, Arabic Islam. Moreover, theological interpretations applied from one tradition to another are more likely to obfuscate rather than illuminate. In this case, we have seen how a 'theology of fear' is unhelpfully reductionist in understanding a Muslim sense of piety, and that the English term 'piety' itself needs, in certain contexts, to be replaced by somewhat more awkward circumlocutions. One way of advancing appreciation of the concept in the Islamic tradition is searching the discussions of the Qur'anic commentators on the passages where a problematic concept is found. In the case of $t a q w \bar{a}$, this led to the domain of commands and prohibitions related to rituals, especially to prohibitions concerning food and the conditions that rendered the divine prohibition more flexible. Here the clearest line is drawn between the Qur'anic community and those designated as idolaters (mushrikūn). For the former, taqwā informs an individual's mood and action while the standard whereby both mood and action are judged lies outside the individual. «Similarly», says Fazlur Rahman, «in the case of the collective performance of a society, both the final criterion of judgement upon it and the 
judgement itself transcend that society.» ${ }^{25}$ For the Qur'anic community, food is made lawful by pronouncing upon it the name of God. The food of idolaters whose lawfulness is determined by the customs of the community and not by individual or collective taqwä, is simply food of the gods.

\section{ABSTRACT}

The paper explores a central concept in the Islamic tradition, namely 'piety' (taqwā) as it appears in the Qur'an and certain early commentaries. Problems arise, however, when approaching the concept through translations of the Qur'an into European languages (in this paper, examples are drawn from English and Spanish) which frequently convey the equivalence of taqwā with 'fear'. By examining a key Qur'anic passage (Q 2:177) the paper leads to a discussion by the commentators al-Tabari and Ibn Kathīr of rituals related to food taboos, as a means of illuminating a fuller meaning of the Islamic notion of «piety».

\section{RESUMEN}

Este artículo analiza un concepto fundamental en la tradición islámica, el de «piedad» o taqwā tal como aparece en el Corán y algunos comentarios tempranos. Los problemas surgen cuando se intenta la aproximación al concepto a través de las traducciones del Corán a lenguas europeas (en este artículo los ejemplos se toman del inglés y del español) que a menudo proponen «temor» como equivalente a taqwā. $\mathrm{Al}$ examinar un pasaje coránico clave (2:177) el artículo conecta con la discusión de los comentadores al-Ṭabarī e Ibn Katīr de rituales relacionados con tabúes alimenticios, como medio de iluminar de manera más clara el concepto islámico de piedad.

${ }^{25}$ Rahman, Major Themes, p. 29, explains that the sense of taqwä may be best conveyed by the term 'conscience' if the object of conscience is understood to transcend it. 